\title{
Magnitude and variability of methane production and concentration in tropical coastal lagoons sediments
}

\author{
Magnitude e variabilidade da produção e concentração \\ de metano no sedimento de lagoas costeiras tropicais
}

\begin{abstract}
Antonella Petruzzella ${ }^{1}$, Claudio Cardoso Marinho ${ }^{1}$,
Lúcia Fernandes Sanches ${ }^{1}$, Murilo Minello ${ }^{2}$ and Francisco de Assis Esteves ${ }^{1}$

${ }^{1}$ Laboratório de Limnologia, Departamento de ecologia, Centro de Ciências da Saúde - CCS, Universidade Federal do Rio de Janeiro - UFRJ, Cidade Universitária, Ilha do Fundão, CP 68020, CEP 21940-540, Rio de Janeiro, RJ, Brazil

e-mail: antonellabio@gmail.com; clcamar@biologia.ufrj.br; luciafernandessanches@yahoo.com.br; festeves@biologia.ufrj.br

${ }^{2}$ Instituto Federal de Educação, Ciência e Tecnologia do Rio de Janeiro - IFRJ, Campus Arraial do Cabo, Rua José Pinto de Macedo s/n, Prainha, CEP 28930-000, Arraial do Cabo, RJ, Brazil e-mail: murilo.minello@ifrj.edu.br
\end{abstract}

\begin{abstract}
Aim: Coastal wetlands are potential zones for methane $\left(\mathrm{CH}_{4}\right)$ production. The present study aims to evaluate the spatial variation of $\mathrm{CH}_{4}$ production and concentration in ten tropical coastal lagoons, the influence of aquatic macrophytes on the sediment $\mathrm{CH}_{4}$ concentration and how the magnitude of these potential $\mathrm{CH}_{4}$ production rates compare to those in other ecosystems. Methods: Sediments were sampled in ten coastal lagoons, with one site in the limnetic region and another site in aquatic macrophyte stands when they were present in the littoral region. We measured the $\mathrm{CH}_{4}$ production as a potential rate, and $\mathrm{CH}_{4}$ concentration was directly measured from sediment samples. Results: The highest potential $\mathrm{CH}_{4}$ production (PMP) rates were found in alkaline and hypersaline lagoons. However, Cabiúnas, which is a freshwater lagoon densely colonized by aquatic macrophytes, also exhibited a high PMP rate. We also observed that the sediment $\mathrm{CH}_{4}$ concentration in the littoral region was higher than in the limnetic region in all of the investigated lagoons except Paulista, which presented the opposite pattern. The PMP rates observed in the studied lagoons were low compared to other aquatic ecosystems. Conclusion: Our results suggest that the sediments of saline lagoons are important $\mathrm{CH}_{4}$ production sites, and in general, aquatic macrophytes have a positive influence on methanogenesis, which was evident based on the $\mathrm{CH}_{4}$ concentrations present in the sediments of these lagoons. Further studies should focus on the processes underlying the $\mathrm{CH}_{4}$ patterns observed in the tropical coastal lagoons, especially concerning the coupling between $\mathrm{CH}_{4}$ production and concentration.
\end{abstract}

Keywords: methanogenesis, organic matter, littoral region and methane concentration.

Resumo: Objetivo: Áreas alagadas costeiras são zonas potenciais para produçáo de metano $\left(\mathrm{CH}_{4}\right)$. O presente estudo tem como objetivo avaliar a variação espacial da produção e concentração de $\mathrm{CH}_{4}$ em dez lagoas costeiras tropicais, a influência de macrófitas aquáticas na concentração de $\mathrm{CH}_{4}$ no sedimento e como a magnitude dessas taxas de produção potencial de $\mathrm{CH}_{4}$ é em comparaçáo com outros ecossistemas. Métodos: Os sedimentos foram amostrados em dez lagoas costeiras, com um ponto na região limnética e outro ponto nos bancos de macrófita aquática, quando estas estavam presentes na região litorânea. Nós medimos a produçâo de $\mathrm{CH}_{4}$ como uma taxa potencial e a concentração de $\mathrm{CH}_{4}$ foi diretamente medida das amostras de sedimento. Resultados: As maiores taxas de produção potencial de $\mathrm{CH}_{4}(\mathrm{PPM})$ foram encontradas em lagoas alcalinas e hipersalinas. Contudo, Cabiúnas, que é uma lagoa de água doce densamente colonizada por macrófitas aquáticas também exibiu alta taxa de PPM. Nós também observamos que a concentração de $\mathrm{CH}_{4}$ do sedimento na região litorânea foi mais alta que na região limnética em todas as lagoas investigadas, exceto Paulista, que apresentou o padrão oposto. As taxas de produção de $\mathrm{CH}_{4}$ observadas nessas lagoas estudadas foram baixas comparadas com outros ecossistemas aquáticos. Conclusão: Nossos resultados sugerem que os sedimentos de lagoas salinas são importantes sítios produtores de $\mathrm{CH}_{4}$, e em geral, macrófitas aquáticas tem uma influência positiva na metanogênese, o que foi evidente baseado nas concentraçóes de $\mathrm{CH}_{4}$ presentes nos sedimentos dessas lagoas. Estudos adicionais deveriam focar nos processos subjacentes aos padróes do $\mathrm{CH}_{4}$ observados nas lagoas costeiras tropicais, especialmente preocupando-se com o acoplamento entre produção e concentração de $\mathrm{CH}_{4}$.

Palavras-chave: metanogênese, matéria orgânica, região litorânea e concentração de metano. 


\section{Introduction}

Methane $\left(\mathrm{CH}_{4}\right)$ production in aquatic environments has drawn special attention in the recent years, because the relative increase of $\mathrm{CH}_{4}$ in the atmosphere since pre-industrial time is approximately $150 \%$, compared to $35 \%$ for $\mathrm{CO}_{2}$ (IPCC, 2007). Furthermore, the global warming potential for $\mathrm{CH}_{4}$ is 25 times higher than that of $\mathrm{CO}_{2}$ (over a 100 year period - (IPCC, 2007)). $\mathrm{CH}_{4}$ is produced biologically by methanogenesis, which is the pathway for mineralizing organic carbon compounds in anoxic conditions and substrate availability (Segers, 1998; Laanbroek, 2010). Methanogenic microorganisms perform this process, generally Archaea, which only occurs in anaerobic environments, such as the sediment of aquatic environments, where methanogenesis is one of the most important processes of organic matter (OM) degradation (Schulz and Conrad, 1995).

Coastal wetlands are potential zones for the production of $\mathrm{CH}_{4}$ (Purvaja and Ramesh, 2001), but the overall ecological factors governing these rates could be very distinct among locations (Gonsalves et al., 2011). Several environmental factors may influence methanogenesis, such as salinity, temperature, $\mathrm{pH}$ and microbial interactions with other anaerobic metabolic groups, such as iron (Fe3+)-reducing bacteria, acetogenic bacteria and sulfate-reducing bacteria (Marinho et al., 2012). Additionally, the presence of aquatic macrophytes has been pointed as a factor that significantly influences $\mathrm{CH}_{4}$ dynamics (Whiting and Chanton, 1993; Fonseca et al., 2004; Laanbroek, 2010).

Coastal aquatic ecosystems are generally shallow, allowing substantial development of aquatic macrophytes (Esteves, 2011). The presence of these plants promotes direct and indirect influences on $\mathrm{CH}_{4}$ dynamics. First, they are a source of $\mathrm{OM}$ to methanogens (Neue et al., 1997), which can increase $\mathrm{CH}_{4}$ production (Conrad, 2007). Second, aquatic macrophytes act on $\mathrm{CH}_{4}$ oxidation, a process that is the reverse of methanogenesis. The roots and rhizomes of macrophytes enhance sediment oxygenation, which allows the growth of the methanotrophic bacteria responsible for the oxidation of $\mathrm{CH}_{4}$ into $\mathrm{CO}_{2}$ (King, 1994). Third, aquatic macrophytes works as a route to release $\mathrm{CH}_{4}$ to the atmosphere, through their internal system for gas transport (Boon and Sorrell, 1995; Yavitt and Knapp, 1995; Kulshreshtha et al., 2000). Using this route the $\mathrm{CH}_{4}$ can release direct from the sediment to the atmosphere without contact with the water column. Thus, the same ecosystem could have patches with different $\mathrm{CH}_{4}$ production dynamics and $\mathrm{CH}_{4}$ concentrations, according to the presence of aquatic macrophytes.

Another important feature of coastal aquatic environments is their proximity to the sea, which can profoundly modify the water chemistry, especially in terms of $\mathrm{pH}$ and salinity (Smith, 1994). Methanogens are often found in a wide range of environments, and these organisms have evolved several strategies that enable them to survive and proliferate in environments of varied ionic composition and salinity, ranging from freshwater to hypersaline habitats (Zinder, 1993; Martin et al., 1999). However, competition for substrate with sulfate-reducers tends to be higher in coastal environments, where the sulfate concentration is increased due to proximity to the sea. In these ecosystems, sulfate reduction may be favored over methanogenesis, because sulfate reduction is more energetically advantageous in relation to the substrates common to both of the types of microorganisms (Lyimo et al., 2002), diminishing the overall potential of coastal lagoons for $\mathrm{CH}_{4}$ production.

Studies of the dynamics of $\mathrm{CH}_{4}$ production and concentration in the sediments of aquatic coastal environments have become more important as the concentration of this greenhouse gas has increased in the atmosphere throughout the years (Zaiss, 1996; Furtado et al., 2002; Fonseca et al., 2004). In general, the wetlands are considered the main natural source of the atmospheric $\mathrm{CH}_{4}$ (Wuebbles and Hayhoe, 2002) that currently contributes approximately $20 \%$ to the global warming effect (Neue et al., 1997). Through extensive field sampling, the present study aims to evaluate: (1) the variation of $\mathrm{CH}_{4}$ production and concentration in ten coastal aquatic ecosystems (2) the spatial variation of sediment $\mathrm{CH}_{4}$ concentration due to the occurrence of aquatic macrophytes and (3) how the magnitude of these potential $\mathrm{CH}_{4}$ production rates compares to other ecosystems.

\section{Material and Methods}

\subsection{Study area}

This study was conducted in 10 coastal lagoons located in the northern region of the state of Rio de Janeiro, Brazil $\left(22^{\circ}-22^{\circ} 30^{\prime} \mathrm{S}\right.$ and $41^{\circ} 15^{\prime}-42^{\circ}$ $\mathrm{W}$ - Figure 1). Eight of the lagoons are situated at the Restinga de Jurubatiba National Park (Cabiúnas, Comprida, Carapebus, Paulista, Garças, Piripiri, Visgueiro and Preta lagoons), and the remaining 


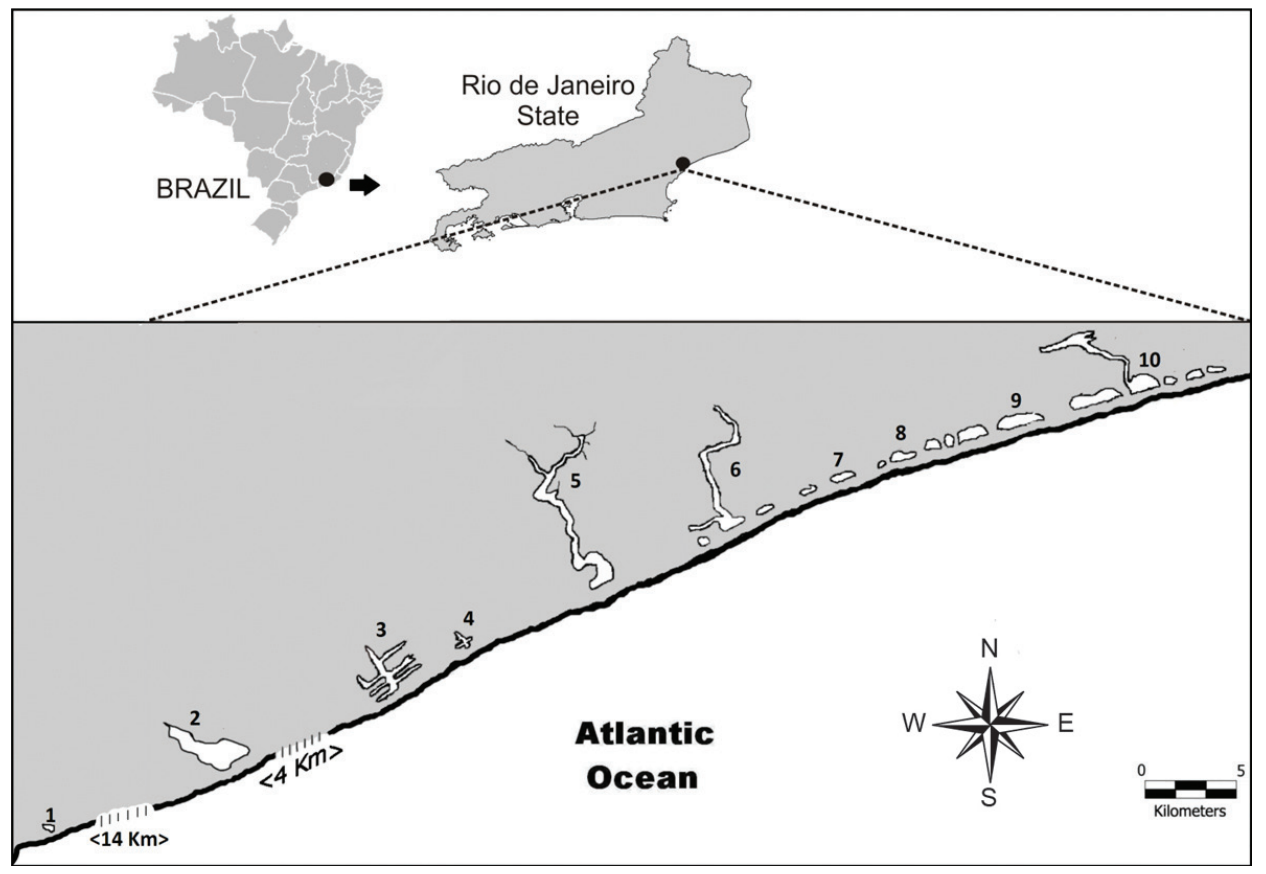

Figure 1. Map illustrating the geographical position of the 10 coastal lagoons. The lagoons are numbered as follows: 1) Iodada, 2) Imboassica, 3) Cabiúnas, 4) Comprida, 5) Carapebus, 6) Paulista, 7) Garças, 8) Piripiri, 9) Visgueiro and 10) Preta.

two are in the urban areas of the cities of Macae and Rio das Ostras (Imboassica and Iodada lagoon, respectively). The climate of the region is characterized as tropical sub-humid/humid; the mean annual temperature varies from $24.7^{\circ} \mathrm{C}$ to $21.4{ }^{\circ} \mathrm{C}$, and the mean annual precipitation is $1000 \mathrm{~mm}$ (INMET, 2003).

These lagoons were formed by movements of marine transgression and regression during glacial and interglacial periods, and are characterized by a sandbar that separates them from the sea (Esteves, 2011). Although these coastal lagoons resulted from the same process, their geneses were different, resulting in a wide range of inland aquatic ecosystems with different sizes, morphometries, water chemistry, landscape positions and trophic status (Caliman et al., 2010). All of the studied lagoons are shallow, not exceeding $3.0 \mathrm{~m}$ water depth and present substantial natural differences in their limnological parameters, particularly in terms of salinity, $\mathrm{pH}$ and sulfate and nutrient concentrations (Table 1). Moreover, the Cabiúnas, Carapebus, Comprida, Imboassica, Iodada and Paulista lagoons exhibited areas colonized by aquatic macrophytes, and the most frequently observed species were Typha domingensis Pers., Eleocharis interstincta (Vahl) Roem. \& Schult., Nymphaea ampla Salisb. and Potamogeton stenostachys K. Schum.

\subsection{Sampling}

The sediment samples reported in this article were collected using acrylic core tubes during December of 2002. One site was collected in the limnetic region of all of the lagoons. In the Cabiúnas, Carapebus, Comprida, Imboassica, Iodada and Paulista lagoons, we also sampled one additional site within aquatic macrophyte stands in the littoral region. The littoral region in all of these lagoons was dominated by Typha domingensis stands, except for Comprida, which was predominantly colonized by Eleocharis interstincta stands.

\subsection{Potential $\mathrm{CH}_{4}$ production of the sediment (PMP)}

The sediment sampled in the cores was put into plastic bags and kept in a refrigerator $\left(5^{\circ} \mathrm{C}\right)$ for 2 days until the incubation. Six grams of the sediment collected was transferred to $25 \mathrm{ml}$ flasks, and $3 \mathrm{ml}$ of water from the lagoon was added. The flasks $(n=7)$ were closed with rubber stoppers, and the residual $\mathrm{CH}_{4}$ and $\mathrm{O}_{2}$ was removed by flushing with $\mathrm{N}_{2}$ for 1 min, creating an anoxic and $\mathrm{CH}_{4}$ free condition. The flasks were incubated statically in the dark in a constant temperature $\left(25 \pm 0.5^{\circ} \mathrm{C}\right)$ for 5 days. The $\mathrm{CH}_{4}$ concentration in the headspace was measured by GC analysis (VARIAN Star 3400 - Varian Co., USA), with a FID detector temperature of 
Table 1. Limnological parameters (depth, salinity, $\mathrm{pH}$, pore water sulfate concentration and total nitrogen and phosphorus levels in water and N:P ratio) of the ten investigated coastal lagoons.

\begin{tabular}{|c|c|c|c|c|c|c|c|}
\hline Lagoons & Depth (m) & Salinity (\%o) & $\mathrm{pH}$ & $\begin{array}{c}\text { Sulfate } \\
\text { (mM) }\end{array}$ & $\begin{array}{c}\text { Total Nitrogen } \\
(\mu \mathrm{M})\end{array}$ & $\begin{array}{c}\text { Total Phosphorus } \\
(\mu \mathrm{M})\end{array}$ & $N: P$ \\
\hline Imboassica* & 1.10 & 2.5 & 7.52 & 0.71 & 40.07 & 1.28 & 31 \\
\hline lodada & 1.80 & 0.1 & 5.16 & 0.33 & - & - & - \\
\hline Cabiúnas* & 2.30 & 0.5 & 6.81 & 0,97 & 55.59 & 0.36 & 154 \\
\hline Comprida* & 1.10 & 0.1 & 4.83 & 0.31 & 64.53 & 0.53 & 122 \\
\hline Carapebus* & 0.80 & 4.1 & 7.48 & 2.41 & 66.95 & 0.62 & 108 \\
\hline Piripiri* & 1.10 & 69.1 & 8.58 & 4.26 & 83.45 & 1.02 & 82 \\
\hline Paulista* & 1.60 & 3.3 & 4.19 & 4.01 & 48.45 & 0.45 & 108 \\
\hline Garças* & 0.10 & 1.5 & 3.55 & 6.64 & 121.29 & 1.84 & 66 \\
\hline Preta* & 0.60 & 100 & 8.40 & 1.56 & 43.07 & 1.33 & 32 \\
\hline Visgueiro* & 0.10 & 160 & 8.28 & 1.01 & 45.64 & 2.09 & 22 \\
\hline
\end{tabular}

*Mean total nitrogen and phosphorus. The data were collected between July 2000 and February 2003 (EnrichPrast et al., 2004).

$220^{\circ} \mathrm{C}$, an injector temperature of $120^{\circ} \mathrm{C}$, a $1 \mathrm{~m}$ Poropak-Q column (60/100 mesh) at $85^{\circ} \mathrm{C}$ and $\mathrm{N}_{2}$ as the carrier gas.

\section{4. $\mathrm{CH}_{4}$ concentration in the sediment}

Sediment samples $(5 \mathrm{~mL})$ were collected using plastic syringes $(n=3)$. The samples were stored in $25 \mathrm{ml}$ flasks with $5 \mathrm{~mL}$ of $\mathrm{NaOH}(4 \%)$ to inhibit biological activity and expel the methane from the pore water (Casper, 1992). The flasks were closed with rubber stoppers and then shaken. The $\mathrm{CH}_{4}$ concentration in the flasks' headspace was measured as described previously earlier in the PMP section.

\subsection{Other measurements}

The salinity was measured using a portable salinity, conductivity and temperature analyzer (YSI 30/10 FT), $\mathrm{pH}$ was mesuared using an Analion $\mathrm{pH}$ meter PM608, and depth was measured using a Secchi disc. The sulfate concentration in the sediment pore water was determined by the formation of barium sulfate (APHA, 1998). The remaining data were obtained from the Brazilian Long Term Ecological Research Program (PELD-LTER- site 5) and the ECOLAGOAS Project database.

\subsection{Data analyses}

After testing for normality (using a KolmogorovSmirnov test) and homogeneity of variance, nonparametric analyses were used when a normal distribution was not observed. All of the statistical analyses were computed with GraphPad Prism 5.0 for Windows. We assumed a significant level of $\alpha=0.05$ to indicate statistically significant difference.

Differences in potential $\mathrm{CH}_{4}$ production (PMP) rates among all of the lagoons were evaluated using a Kruskal-Wallis one-way analysis of variance (ANOVA). We used Dunn's post-hoc test to evaluate differences among the lagoons. Differences among the sediment $\mathrm{CH}_{4}$ concentrations of the ten lagoons were tested using one-way ANOVA with a Tukey post-hoc test. We also investigated differences in the sediment $\mathrm{CH}_{4}$ concentration between the limnetic and littoral regions (aquatic macrophytes stands) for all of the lagoons that exhibited extensive aquatic macrophyte stands: the Cabiúnas, Carapebus, Comprida, Imboassica, Iodada and Paulista lagoons. A paired t-test was used to compare the means among these observations.

\section{Results}

The limnological parameters measured in the ten investigated coastal lagoons are presented in Table 1. All of the lagoons were shallow (0.10-2.30 $\mathrm{m}$ ) and did not exceed $2.5 \mathrm{~m}$ water depth, which is characteristic of this ecosystem type as previously described. The salinity values varied considerably among the lagoons, ranging from freshwater $(<5.0 \%$ o $)$ to hypersaline $(>40 \%$ o). Almost all of the studied lagoons are freshwater bodies, except Piripiri, Preta and Visgueiro, which exhibit salinity values greater than seawater $(35 \%)$, reaching levels up to $100 \%$ o (Table 1 ). We found the highest $\mathrm{pH}$ values in these hypersaline environments, exceeding 8. The lowest $\mathrm{pH}$ values were found in the Garças, Paulista, Comprida and Iodada lagoons, ranged from 3.55 to 5.16 (Table 1 ). The pore water sulfate concentration varied from $0.3 \mathrm{mM}$ in Comprida to $6.64 \mathrm{mM}$ in Garças Lagoon. The total nitrogen concentration in the water ranged from $40.07 \mu \mathrm{M}$ in Imboassica Lagoon to $121.19 \mu \mathrm{M}$ in Garças Lagoon (Table 1), where the values were considerably higher 
than in the other lagoons. The total phosphorus in the water ranged from $0.36 \mu \mathrm{M}$ in Cabiúnas to $2.09 \mu \mathrm{M}$ in Visgueiro Lagoon. The Imboassica, Preta and Visgueiro lagoons presented the lowest $\mathrm{N}: \mathrm{P}$ ratios of 32, 31 and 22, respectively, whereas Cabiúnas had the highest ratio, reaching 154.

\subsection{Potential $\mathrm{CH}_{4}$ production rates of nine coastal lagoons}

The PMP of Comprida Lagoon was not included in the statistical analyses, thus, only nine coastal lagoons were considered. Figure 2 shows a wide PMP variation among the lagoons, ranging from undetectable in Garças Lagoon to $4.33 \mathrm{nmol}$ $\mathrm{CH}_{4} \mathrm{~g}^{-1}$ day $^{-1}$ in Visgueiro Lagoon. Visgueiro exhibited the greatest $\mathrm{CH}_{4}$ production rate of all of the lagoons, but the rate was not significantly different from that in Preta, Piripiri, Imboassica and Cabiúnas. In addition, there was no significant difference in PMP among Carapebus, Paulista, Imboassica, Garças and Iodada, which showed low $\mathrm{CH}_{4}$ production rates.

\subsection{Sediment $\mathrm{CH}_{4}$ concentration}

\subsubsection{Differences among the ten coastal lagoons}

The mean pore water $\mathrm{CH}_{4}$ concentration of the ten coastal lagoons ranged from $8.13 \mu \mathrm{M}$ in Imboassica Lagoon to $420.63 \mu \mathrm{M}$ in Preta Lagoon (Figure 3A). The former was significantly different from the others, and the remaining lagoons were all statistically similar (Figure 3A).

\subsubsection{Differences between the limnetic and} littoral region (aquatic macrophytes stands)

The pore water $\mathrm{CH}_{4}$ concentration measured in the limnetic region and within aquatic macrophyte stands varied considerably between the two regions (Figure 3B). Iodada Lagoon had the greatest

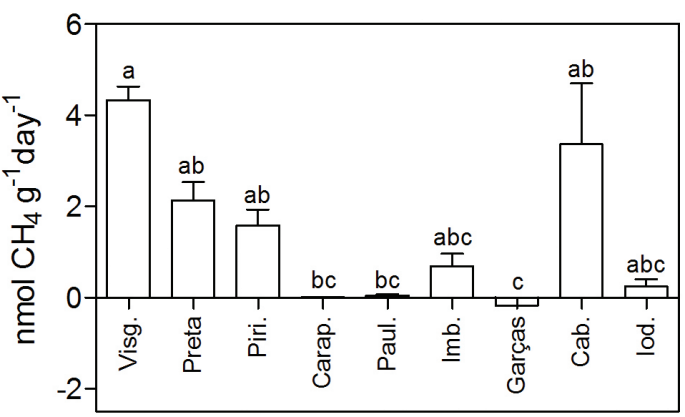

Figure 2. Potential $\mathrm{CH}_{4}$ production rates of nine coastal lagoons. Visg.-Visgueiro, Preta-Preta, Piri.- Piripiri, Carap.-Carapebus, Paul.-Paulista, Imb.-Imboassica, Garças-Garças, Cab.-Cabiúnas and Iod.-Iodada. sediment $\mathrm{CH}_{4}$ concentration, with $2712.03 \mu \mathrm{M}$ in the littoral region. Imboassica Lagoon did not show the highest littoral region $\mathrm{CH}_{4}$ concentration values, but these values were eighty three times higher than those in the Imboassica limnetic region. Overall, the $\mathrm{CH}_{4}$ concentration in the littoral region was significantly different and higher than that in the limnetic region in all of the investigated lagoons except Paulista, which presented the opposite pattern (Figure 3B).

\section{Discussion}

Hypersaline and freshwater lagoons can be found side-by-side, depending on the particular drivers of hydrological balance, such as local precipitation, watershed inflow, evaporation rate and seawater influence (Kjerfve, 1994), which demonstrates that salt balance is intimately related to, but not limited to, water balance (Smith, 1994).
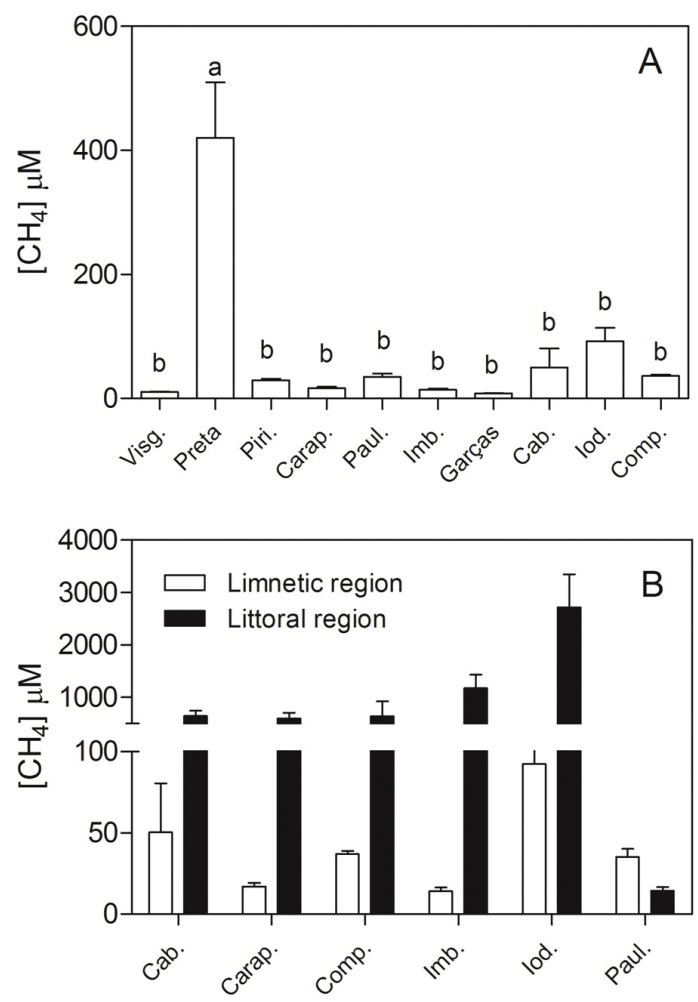

Figure 3. Sediment $\mathrm{CH}_{4}$ concentrations in pore water. A- Ten coastal lagoons. Visg.-Visgueiro, Preta-Preta, Piri.-Piripiri, Carap.-Carapebus, Paul.-Paulista, Imb.Imboassica, Garças-Garças, Cab.-Cabiúnas, Iod.-Iodada and Comp.-Comprida. B- Difference between the limnetic and littoral regions of all of the lagoons that contain aquatic macrophyte stands. The lagoons are named as follows: Cab.-Cabiúnas, Carap.-Carapebus, Comp.-Comprida, Imb.-Imboassica, Iod.- Iodada and Paul.-Paulista. The bars indicate the means \pm SEMs. 
The salinity also influences the $\mathrm{pH}$, and most known methanogens are neutrophilic, suggesting that $\mathrm{pH}$ constrains $\mathrm{CH}_{4}$ production in wetlands. Our results indicated that the highest PMP rates were found in alkaline and hypersaline lagoons. However, some studies that quantitatively assessed the $\mathrm{pH}$ influence on methanogenesis in wetlands do not confirm a positive relationship between $\mathrm{pH}$ and $\mathrm{CH}_{4}$ production rates (Dunfield et al., 1993; Bergman et al., 1998). In addition to high $\mathrm{pH}$ values, high primary productivity and high sulfate concentrations are characteristic of many hypersaline aquatic systems (Oren, 2002). Sulfate concentrations are high in coastal lagoons compared to freshwater systems (only 100-200 $\mu \mathrm{M}$ ) but lower in relation to seawater and estuarine systems (20$30 \mathrm{mM}$ ) (Capone and Kiene, 1988). Our results suggests that the present sulfate concentration of the coastal lagoons evaluated in this study does not affect methanogenesis because, high $\mathrm{CH}_{4}$ production values were found in the lagoons with high sulfate concentrations, highlighting the diminished importance of competition between the methanogenesis and sulfate reduction metabolic pathways in these systems, which is unexpected (Lovley et al., 1982; Oremland and Poucin, 1982).

High sulfate reduction rates have been measured in hypersaline brines, microbial mats and aquatic sediments at salinities exceeding 20\%o (Brandt et al., 2001; Daffonchio et al., 2006). Although some studies indicate that sulfate concentrations might not constrain $\mathrm{CH}_{4}$ production, sulfate-reducing bacteria usually compete with methanogens, inhibiting $\mathrm{CH}_{4}$ production by lowering the hydrogen partial pressure below a threshold level necessary for hydrogen utilization by methanogens (Lovley et al., 1982; Boone, 1991). In contrast, our results indicate that the Vigueiro, Preta and Piripiri lagoons showed the greatest PMP rates, suggesting that the competition between these two groups of bacteria is weak, which can be explained by the presence of noncompetitive substrates, such as betaine, trimethylamine and methylated sulfides (Zinder, 1993). Noncompetitive substrates result from organisms' osmoregulatory strategies which consist of an intracellular accumulation of inorganic ions, such as sodium $\left(\mathrm{Na}^{+}\right)$, to survive in salt water. However, high concentrations of inorganic ions often have deleterious effects; thus, these ions are progressively replaced by organic solutes that are produced within organismal cells' (Martin et al., 1999). Therefore, organisms that inhabit high salinity conditions can favor the accrual of these organic solutes, which are used only by methanogens (Martin et al., 1999; Boone, 1991). In addition, the salt influence inhibits the colonization by aquatic macrophytes (Glenn et al., 1995). Without shading by aquatic macrophytes, the benthic compartment can be colonized by microalgae and other microorganisms forming a microbial mat. The Visgueiro and Piripiri lagoons exhibit microbial mats, which can possibly increase the OM input in the system and provide substrates for methanogenesis (Enrich-Prast et al., 2004). Moreover, $\mathrm{C}: \mathrm{N}: \mathrm{P}$ ratios are significant in several important ecological processes, such as litter decomposition (Güsewell and Gessner, 2009). In the present research, the low N:P ratio value in the water of Visgueiro Lagoon (Table 1), can also explain the highest PMP rates observed there, as a function of the labile OM input via particulate deposition in the water column.

In contrast to the hypersaline systems, Cabiúnas is a freshwater lagoon that is densely colonized by aquatic macrophytes and has high PMP rate. The effect of macrophytes on $\mathrm{CH}_{4}$ dynamics is well investigated, and their presence may explain some of the PMP results found for this particular system. Aquatic macrophytes contribute as suppliers of organic material through root exudates and plant litter production, which can account for $50 \%$ of the nutrients and $\mathrm{OM}$ input in an entire aquatic system (Wetzel, 2001). Ding et al. (2002) noted that labile organic carbon for $\mathrm{CH}_{4}$ production is mainly derived from plant litter, which can be more resistant to decomposition, such as emergent macrophytes, or be more labile, such as floating leaves or submerged macrophytes (Farjalla et al., 1999). We believe that OM inputs via macrophytes may subsidize microbiological process in sediments, favoring oxygen consumption and supporting methanogenesis. Particularly in this sampling year, Cabiúnas Lagoon was vastly colonized by the submerged macrophyte Potamogeton stenostachys, and according to Brum and Esteves (2001), this macrophyte species detritus decomposes five times faster than regular emergent macrophyte species that are, usually dominant in these systems. Therefore, because Potamogeton stenostachys is a labile OM source and abundant in the sediment of Cabiúnas Lagoon, it possibly altered the OM input into the sediment, enhancing methanogenesis. Our results consistently indicate a positive influence of the presence of aquatic macrophytes, which is also corroborated by the comparison between limnetic and littoral region pore water $\mathrm{CH}_{4}$ concentrations 
in our study and others (Chan et al., 2002; Bastviken et al., 2010; Neves et al., 2011). Almost all of the lagoons showed much higher sediment $\mathrm{CH}_{4}$ concentrations in the littoral region than in the limnetic region. Such differences have also been reported by Fonseca et al. (2004) in the Cabiúnas Lagoon, who measured high $\mathrm{CH}_{4}$ concentrations in sediments colonized by macrophytes such as Typha domingensis.

An interesting pattern observed in the present study is that high production rates are not always followed by a high $\mathrm{CH}_{4}$ concentration in sediments. In the limnetic region, the pore water $\mathrm{CH}_{4}$ concentration, even in the lagoons that showed high PMP rates, was relatively lower and not significantly different among the lagoons, except for Preta Lagoon. We believe that other factors can influence the $\mathrm{CH}_{4}$ concentration. The $\mathrm{CH}_{4}$ produced in anaerobic sediments of these ecosystems, can be oxidized in the aerobic zone by methanotrophic bacteria, or even anaerobically, often related to sulfate reduction (Schubert et al., 2010; Meulepas et al., 2010). During this process, these organisms consume large amounts of $\mathrm{CH}_{4}$, a process that has been a biogeochemical enigma for many years regarding anoxic marine sediments. Nearly $90 \%$ of the $\mathrm{CH}_{4}$ produced in anoxic marine sediments is recycled through anaerobic oxidation processes (Hinrichs et al., 2000). Anaerobic $\mathrm{CH}_{4}$ oxidation in freshwater systems could be possible if sulfate concentrations reach approximately 1 $\mathrm{mM}$ (Segers, 1998), a requirement that is met by the coastal lagoons in the present study. In summary, the sediment $\mathrm{CH}_{4}$ concentration results from the balance between methanogenesis and methanotrophy (aerobic or anaerobic oxidation). The low depth of the water column in Visgueiro Lagoon and other shallow aquatic bodies can favor mixing due to wind action, causing system oxygenation, which can result in high $\mathrm{CH}_{4}$ oxidation and/or inhibition of the $\mathrm{CH}_{4}$ production in the surface sediments. Such a process could, also explain the high PMP rates and low pore water $\mathrm{CH}_{4}$ concentration in the sediments of the lagoons studied here.

Rates of PMP have been determined in a large number of studies in various natural wetlands, rice fields and other ecosystems. The available data (Table 2) suggest that rice paddy soils are the greatest producers, perhaps due to the large amount of available organic carbon and anaerobic conditions, a hypothesis that is also corroborated by other studies (Reeburgh, 1996; Yang and Chang, 1998). Compared to other ecosystems, the $\mathrm{CH}_{4}$ production rates observed in the studied lagoons were low. For the shallow Arabian Sea, researchers observed $\mathrm{CH}_{4}$ production of $150 \mathrm{nmol} \mathrm{g}{ }^{-1}$ day $^{-1}, 95 \mathrm{nmol}$ $\mathrm{g}^{-1}$ day $^{-1}$ in a mangrove estuary and a surprisingly high rate of $36 \mathrm{nmol} \mathrm{g}^{-1}$ day $^{-1}$ in the sandy beach sediments. Marinho et al. (2012) also investigated the $\mathrm{CH}_{4}$ production rate in mangroves, and their results were similar to what we found in some coastal lagoons. Zaiss (1996) found $87 \mathrm{nmol} \mathrm{g}^{-1} \mathrm{day}^{-1}$ in a freshwater lagoon. However, the greatest PMP rate of a freshwater lagoon (Cabiúnas) in our study was only $3.36 \mathrm{nmol} \mathrm{g}^{-1} \mathrm{day}^{-1}$. In an earlier study

Table 2. Comparison of the potential methane production (PMP) rates from different ecosystem types.

\begin{tabular}{|c|c|c|}
\hline Ecosystem Type & $\begin{array}{c}\text { Sediment PMP rates at } 25^{\circ} \mathrm{C} \\
\left(\mathrm{nmol} \mathrm{CH}{ }_{4} \mathrm{~g}^{-1} \text { day }^{-1}\right)\end{array}$ & References \\
\hline Salt marsh & 1.3 & Zaiss, 1996 \\
\hline Vigueiro Lagoon & 4.33 & Present study \\
\hline Zoige alpine wetland, Tibet & $1.75^{*}$ & Tian et al., 2011 \\
\hline Ace lake, Antarctica & 2.5 & Franzmann et al., 1991 \\
\hline Mangrove Coroa Grande, Brazil & 2.7 to 3.2 & Marinho et al., 2012 \\
\hline Arabian Sea - Shallow Arabian Sea & 150 & Gonsalves et al., 2011 \\
\hline Mangrove estuary & 95 & Gonsalves et al., 2011 \\
\hline Sandy beach & 36 & Gonsalves et al., 2011 \\
\hline $\begin{array}{l}\text { Rice paddy soils, } \\
\text { Philippines } \\
\text { Italy }\end{array}$ & $\begin{array}{l}999^{*} \\
1250^{*}\end{array}$ & $\begin{array}{l}\text { Yao et al., } 1999 \\
\text { Yao et al., } 1999\end{array}$ \\
\hline $\begin{array}{l}\text { Hudson Bay lowland - } \\
\text { Sphagnum-dominated peatland } \\
\text { Sedge-dominated peatland }\end{array}$ & $\begin{array}{c}10 \\
\approx 12\end{array}$ & Dunfield et al., 1993 \\
\hline Swedish lakes & 0.037 to $3.99^{*}$ & Duc et al., 2010 \\
\hline Freshwater Lagoon & 87 & Zaiss, 1996 \\
\hline Cabiúnas Lagoon & 3.36 & Present study \\
\hline Cabiúnas Lagoon & n.d. & Furtado et al., 2002 \\
\hline
\end{tabular}

*Temperature of the incubation: $30^{\circ} \mathrm{C}$. 
performed by Furtado et al. (2002) in the same lagoon, PMP was undetectable, possibly due to the absence of substrates. However, in general, regions colonized by aquatic macrophytes often exhibit high PMP rates (Dunfield et al., 1993).

Methane production is an important environmental issue in the context of concerns about global climate change. The relative contributions of different natural sources to global atmospheric methane emissions are $76 \%$ from wetlands, $11 \%$ from termites, $8 \%$ from oceans and 5\% from hydrates (IPCC, 2001). Despite the fact that wetlands only occupy $3.8 \%$ of the earth's land surface (Aselmann and Crutzen, 1989), they have an important role in $\mathrm{CH}_{4}$ dynamics. Our results suggest that the sediments of saline lagoons are important $\mathrm{CH}_{4}$ production sites, and aquatic macrophytes generally have a positive influence on methanogenesis, which was evident in the $\mathrm{CH}_{4}$ concentration in the sediments. Although our study does not provide all of information that we need to explain differences in $\mathrm{CH}_{4}$ production rates and concentrations, we were able to provide a fundamental background on the main environmental factors acting on these particular systems. Due to the environmental complexity usually associated with these aquatic ecosystems, further studies should focus on the processes underlying the $\mathrm{CH}_{4}$ patterns observed in these systems, especially regarding the coupling between $\mathrm{CH}_{4}$ production and concentration.

\section{Acknowledgements}

The authors are grateful to CNPQ, CAPES and Petrobras for the financial support and scholarships and to NUPEM/UFRJ for logistical support. Special thanks to Dr. Rafael Dettogni Guariento for his valuable comments, which greatly improved this manuscript. This work could not have been conducted without his excellent assistance and knowledge.

\section{References}

ASELMANN, I. and CRUTZEN, PJ. 1989. Global distribution of natural freshwater wetlands and rice paddies, their net primary productivity, seasonality and possible methane emissions. Journal of Atmospheric Chemistry, vol. 8, p. 307-358. http:// dx.doi.org/10.1007/BF00052709

American Public Health Association - APHA. 1998. Standard methods for the examination of water and wastewater. 20th ed. Washington: APHA.
BASTVIKEN, D., SANTORO, AL., MAROTTA, H., PINHO, LQ., CALHEIROS, DF., CRILL, P. and ENRICH-PRAST, A. 2010. Methane emissions from Pantanal, South America, during the low water season: Toward more comprehensive sampling. Environmental Science, vol. 4, p. 54505455. PMid:20568738. http://dx.doi.org/10.1021/ es 1005048

BERGMAN, I., SVENSON, BH. and NILSSON, M. 1998. Regulation of methane production in a Swedish acid mire by $\mathrm{pH}$, temperature and substrate. Soil Biology and Biochemistry, vol. 30, p. 729-741. http://dx.doi.org/10.1016/S0038-0717(97)00181-8

BOON, PI. and SORRELL, BK. 1995. Methane fluxes from an Australian floodplain wetland: the importance of emergent macrophytes. Journal of the North American Benthologic Society, vol. 14, no. 4, p. 582-598. http://dx.doi.org/10.2307/1467543

BOONE, DR. 1991. Ecology of methanogenesis. In ROGERS, JE. and WHITMAN, WB., eds. Microbial production and consumption of greenhouse gases: methane, nitrogen oxides and halomethanes. Washinghton: American Society for Microbiology. p. 57-70.

BRANDT, KK., VESTER, F., JENSEN, AN. and INGVORSEN, K. 2001. Sulfate reduction dynamics and enumeration of sulfate-reducing bacteria in hypersaline sediments of the Great Salt Lake (Utah, USA). Microbial Ecology, vol. 41, p. 1-11. PMid:11252159.

BRUM, PR. and ESTEVES, FA. 2001. Dry weight loss and chemical variation in the detritus of three tropical aquatic macrophyte species (Eleocharis interstincta, Nymphaea ampla and Potamogeton stenostachys) during decomposition. Acta Limnologica Brasiliensia, vol. 13, no.1, p. 61-73.

CALIMAN, A., CARNEIRO, LS., SANTANGELO, JM., GUARIENTO, RD., PIRES, APF., SUHETT, AL., QUESADO, LB., SCOFIELD, V., FONTE, ES., LOPES, PM., SANCHES, LF., AZEVEDO, FD., MARINHO, CC., BOZELLI, RL., ESTEVES, FA. and FARJALLA, VF. 2010. Temporal coherence among tropical coastal lagoons: a search for patterns and mechanisms. Brazilian Journal of Biology, vol. 70, no. 3, p. 803-814. PMid:21085785. http://dx.doi. org/10.1590/S1519-69842010000400011

CAPONE, DG. and KIENE, RP. 1988. Comparison of microbial dynamics in marine and freshwater sediments: Contrasts in anaerobic carbon catabolism. Limnology and Oceanography, vol. 33, no. 4, p. 725749.

CASPER, P. 1992. Methane production in lakes of different trophic state. Archiv für Hydrobiologie Beihefte Ergebnisse der Limnologie, vol.37, p. 149-154. 
CHAN, OC., WOLF, M., HEPPERLE, D. and CASPER, P. 2002. Methanogenic archael community in the sediment of an artificially portioned acidic bog lake. FEMS Microbiology Ecology, vol.42, p. 119-129. PMid:19709271. http://dx.doi. org/10.1111/j.1574-6941.2002.tb01001.x

CONRAD, R. 2007. Microbial ecology of methanogens and methanotrophs. Advances in Agronomy, vol. 96, p. 1-63. http://dx.doi.org/10.1016/S00652113(07)96005-8

DAFFONCHIO, D., BORIN, S., BRUSA, T., BRUSETTI, L., VAN DER WIELEN, PW., BOLHUIS, H., YAKIMOV, MM., D’AURIA, G., GIULIANO, L. and OTHER AUTHORS. 2006. Stratified prokaryote network in the oxicanoxic transition of a deep-sea halocline. Nature, vol. 440, p. 203-207. PMid:16525471. http://dx.doi. org/10.1038/nature04418

DING, W., CAI, Z., TSURUTA, H. and LI, X. 2002. Effect of standing water depth on methane emissions from freshwater marshes in northeast China. Atmospheric Environment, vol. 36, p. 5149-5157. http://dx.doi.org/10.1016/S1352-2310(02)00647-7

DUC, NT., CRILL, P. and BASTVIKEN, D. 2010. Implications of temperature and sediment characteristics on methane formation and oxidation in lake sediments. Biogeochemistry, vol. 100, p. 186196.

DUNFIELD, P., KNOWLES, R., DUMONT, R. and MOORE, TR. 1993. Methane production and consumption in temperate and subarctic peat soils: response to temperature and $\mathrm{pH}$. Soil Biology and Biochemistry, vol. 25, no. 3, p. 321-326. http://dx.doi. org/10.1016/0038-0717(93)90130-4

ENRICH-PRAST, A., BOZELLI, RL., ESTEVES, FA. and MEIRELLES, FP. 2004. Lagoas costeiras da restinga de Jurubatiba: Descrição de suas variáveis limnológicas. IN ROCHA, CFD., ESTEVES, FA., and SCARANO, FR., eds. Pesquisas de longa duração na restinga de Jurubatiba. Ecologia, história natural e conservação. p. 245-253.

ESTEVES, FA. 2011. Fundamentos de Limnologia. 3. ed. Rio de Janeiro: Interciência. 826 p.

FARJALLA, VF., MARINHO, CC. and ESTEVES, FA. 1999. Uptake of oxygen in the initial stages of decomposition of aquatic macrophytes and detritus from terrestrial vegetation in a tropical coastal lagoon. Acta limnologica Brasiliensia, vol. 11, no. 2, p. 185-193.

FONSECA, ALS., MINELLO, M., MARINHO, CC. and ESTEVES, FA. 2004. Methane concentration in water column and in pore water of a coastal lagoon (Cabiúnas lagoon, Macaé, RJ, Brazil). Brazilian
Archives of Biology and Technology, vol. 47, no. 2, p. 301-308.

FRANZMANN, PD., ROBERTS, NJ., MANCUSO, CA., BURTON, HR. and McMEEKIN, TA. 1991. Methane production in meromictic Ace Lake, Antarctica. Hydrobiologia, vol. 210, p. 191-201. http://dx.doi.org/10.1007/BF00034677

FURTADO, ALS., CASPER, P. and ESTEVES, FA. 2002. Methanogenesis in an impacted and two dystrophic coastal lagoons (Macaé, Brazil). Brazilian Archives of Biology and Technology, vol. 45, no. 2, p. 195-202.

GLENN, E., THOMPSON, TL., FRYE, R., RILEY, J. and BAUMGARTNER, D. 1995. Effects of salinity on grow and evapotranspiration of Typha domingensis Pers. Aquatic Botany, vol. 52, p. 75-91. http://dx.doi. org/10.1016/0304-3770(95)00492-I

GONSALVES, MJ., FERNANDES, CEG., FERNANDES, SO., KIRCHMAN, DL. and BHARATHI, PAL. 2011. Effects of composition of labile organic matter on biogenic production of methane in the coastal sediments of the Arabian Sea. Environmental Monitoring and Assessment, vol. 182, p. 385-395. PMid:21318266. http://dx.doi. org/10.1007/s10661-011-1883-3

GÜSEWELL, S. and GESSNER, MO. 2009. N:P ratios influence their litter decomposition and colonization by fungi and bacteria in microcosms. Function Ecology, vol. 23, p. 211-219. http://dx.doi. org/10.1111/j.1365-2435.2008.01478.x

HINRICHS, KAI-UWE., SUMMONS, RE., ORPHAN, V., SYLVA, SP.and HAYES, JM. 2000. Molecular and isotopic analysis of anaerobic methaneoxidizing communities in marine sediments. Organic Geochemistry, vol. 31, p. 1685-17001. http://dx.doi. org/10.1016/S0146-6380(00)00106-6

I N S T I T U T O N A C I O N A L D E METEREOLOGIA - INMET. 2003. Clima. Available from: <http://www.inmet.gov.br/html/ clima.php. Acesso em: 2002-2003>.

INTERGOVERNMENTAL PANEL ON CLIMATE CHANGE - IPCC. 2001. IPCC third assessment report and the synthesis report.

INTERGOVERNMENTAL PANEL ON CLIMATE CHANGE - IPCC. 2007. IPCC fourth assessment report, working group 3.

KING, GM. 1994. Associations of methanotrophs with the roots and rhizomes of aquatic vegetation. Applied and Environmental Microbiology, vol. 60, no. 9, p. 3220-3227. PMid:7524441 PMCid:PMC201792.

KJERFVE, B. 1994. Coastal lagoon processes. In KJERFVE, B., ed. Coastal lagoon processes. Elsevier 
Oceanography Series, vol. 60, p. 1-8. http://dx.doi. org/10.1016/S0422-9894(08)70006-0

KULSHRESHTHA, K., SINGH, SN. and AGNIHOTRI, S. 2000. Existence of micropores on the tiller surface of Schoenoplectus subalatus: the probable port for methane emission. Aquatic Botany, vol. 66, p. 241-247. http://dx.doi.org/10.1016/ S0304-3770(99)00075-3

LAANBROEK, HJ. 2010. Methane emission from natural wetlands: interplay between emergent macrophytes and soil microbial processes. A minireview. Annals of Botany, vol. 105, p. 141-153. PMid:19689973 PMCid:PMC2794055. http:// dx.doi.org/10.1093/aob/mcp201

LOVLEY, DR., DWYER, DF. and KLUG, MJ. 1982. Kinetic analysis of competition between sulfate reducers and methanogens for hydrogen in sediments. Applied and Environmental Microbiology, vol. 43, p. 1373-1379. PMid:16346033 PMCid:PMC244242.

LYIMO, TJ., POL, A. and DEN-CAMP, HJMO. 2002. Sulfate reduction and methanogenesis in sediments of Mtoni mangrove forest, Tanzania. AMBIO, vol. 31, no. 7-8, p. 614-616. PMid:12572833.

MARINHO, CC., CAMPOS, EA., GUIMARAES, JRD. and ESTEVES, FA. 2012. Effect of sediment composition on methane concentration and production in the transition zone of a mangrove (Sepetiba Bay, Rio de Janeiro, Brazil). Brazilian Journal of Biology, vol. 72, no. 3, p. 429-436. PMid:22990811. http://dx.doi.org/10.1590/S151969842012000300003

MARTIN, D., CIULla, R. and ROBERTS, M. 1999. Osmoadaptation in Archaea. Applied and Environmental Microbiology, vol. 65, p. 1815-1825. PMid:10223964 PMCid:PMC91261.

MEULEPAS, RJW., JAGERSMA, CG., KHADEM, AF., STAMS, AJM. and LENS, PNL. 2010. Effect of methanogenic substrates on anaerobic oxidation of methane and sulfate reduction by an anaerobic methanotrophic enrichment. Applied Microbiology and Biotechnology, vol. 87, no. 4, p. 1499-1506. PMid:20445975 PMCid:PMC2892604. http:// dx.doi.org/10.1007/s00253-010-2597-0

NEUE, HU., GAUNT, JL., WANG, ZP., BECKERHEIDMANN, P. and QUIJANO, C. 1997. Carbon in tropical wetlands. Geoderma, vol. 79, p. 163-185. http://dx.doi.org/10.1016/S0016-7061(97)00041-4

NEVES, JMCOS., ARAGON, GT. and SILVA FILHO, EV. 2011. Effects of eutrophication and Typha domingensis Pers on methanogenesis in tropical constructed wetland. Acta Limnologica Brasiliensia, vol. 23, no. 2, p. 145-153. http://dx.doi.org/10.1590/ S2179-975X2011000200005
OREMLAND, RS. and POUCIN, S. 1982. Methanogenesis and sulfate reduction: Competitive and noncompetitive substrates in estuarine sediments. Applied and Environmental Microbiology, vol. 44, no. 6, p. 1270-1276. PMid:16346144 PMCid:PMC242184.

OREN, A. 2002. Halophilic microorganisms and their environments. Cellular Origin, Life in Extreme Habitats and Astrobiology, vol. 5. Netherlands: Kluwer, Dordrecht. 575 p.

PURVAJA, R. and RAMESH, R. 2001. Natural and anthropogenic methane emission from coastal wetlands of south India. Environmental Management, vol. 27, p. 547-557. PMid:11289453. http://dx.doi. org/10.1007/s002670010169

REEBURGH, WS. 1996. "Soft spots" in the global methane budget. In LIDSTROM, ME. and TABITA, FR., eds. Microbial Growth on C1 Compounds. Boston: Kluwer Academic Publishers. p. 334-342.

SCHUBERT, CJ., LUCAS, FS., DURISCH-KAISER, E., STIERLI, R., DIEM, T., SCHEIDEGGER, O., VAZQUEZ, F. and MÜLLER, B. 2010. Oxidation and emission of methane in a monomictic lake (Rotsee, Switzerland). Aquatic Sciences, vol. 72, no. 4, p. 455-466. http://dx.doi.org/10.1007/s00027-010$0148-5$

SCHULZ, S. and CONRAD, R. 1995. Effect of algal deposition on acetate and methane concentrations in the profundal sediment of deep lake (Lake Constance). FEMS Microbiology Ecology, vol.16, p. 251-260. http://dx.doi.org/10.1111/j.1574-6941.1995. tb00289.x

SEGERS, R. 1998. Methane production and methane consumption: a review of processes underlying wetland methane fluxes. Biogeochemistry, vol. 41, p. 23-51. http://dx.doi.org/10.1023/A:1005929032764

SMITH, NP. 1994. Water, salt and heat balances of coastal lagoons. In KJERFVE, B., ed. Coastal lagoon processes. Elsevier Oceanography Series, vol. 60, p. 69-102.

TIAN, J., CHEN, H., WANGE, Y. and ZHOU X. 2011. Methane production in relation with temperature, substrate and soil depth in Zoige wetlands on Tibetan Plateau. Acta Ecologica Sinica, vol. 31, no. 2, p. 121-125. http://dx.doi.org/10.1016/j. chnaes.2011.01.002

WETZEL, RG. 2001. Limnology, lake and rivers ecosystems. 3rd ed. San Diego: Academic Press. $1006 \mathrm{p}$.

WHITING, GJ. and CHANTON, JP. 1993. Primary production control of methane emission from wetlands. Nature, vol. 364, p. 794-795. http://dx.doi. org/10.1038/364794a 0 
WUEBBLES, DJ. and HAYHOE, K. 2002. Atmospheric methane and global change. Earth-Science Reviews, vol. 57, p. 177-210. http://dx.doi.org/10.1016/ S0012-8252(01)00062-9

YANG, SS. and CHANG, HL. 1998. Diurnal variation of methane emission from paddy fields at different growth stages of rice cultivation in Taiwan. Agriculture, Ecosystems and Environment, vol. 76, p. $75-84$

YAO, H., CONRAD, R., WASSMANN, R. and NEUE, HU. 1999. Effect of soil characteristics on sequential reductionand methane production in sixteen rice paddy soils from China, the Philippines, and Italy.
Biogeochemistry, vol. 47, p. 269-295. http://dx.doi. org/10.1007/BF00992910

YAVITT, JB. and KNAPP, AK. 1995. Methane emission to the atmosphere through emergent cattail (Typha latifolia L.) plants. Tellus, vol. 47B, p. 521-534.

ZAISS, U. 1996. A comparison of hydrogen sulfide, hydrogen and methane production and consumption in different aquatic ecosystems. Mitteilungen der Internationalen Vereinigung für Limnologie, vol. 25, p. 63-71.

ZINDER, SH. 1993. Physiological ecology of methanogens. In FERRY, JG., ed. Methanogenesis. New York, London: Chapman \& Hall. p. 253-303.

Received: 08 April 2013 Accepted: 25 November 2013 